\title{
Evaluation of selected Polish potato cultivars and breeding lines regarding their resistance against Phytophthora infestans and usefulness for organic farming
}

\section{Ocena wybranych polskich odmian i klonów hodowlanych ziemniaka pod względem poziomu odporności na Phytophthora infestans oraz przydatności do upraw ekologicznych}

\author{
Jarosław Plich*, Beata Tatarowska, Bogdan Flis
}

\begin{abstract}
Summary
The presented studies concern an evaluation of 10 potato cultivars ( 5 starch and 5 table) and 9 selected potato breeding lines regarding their resistance against Phytophthora infestans as well as other traits such as length of vegetation period, yield, tuber size, regularity of tuber shape, depth of eyes. The aim of these studies was to evaluate of the potential usefulness of tested potato cultivars/clones for organic farming. The obtained results indicate that none of the tested table cultivars should be recommended for organic farming, due to their low resistance to $P$. infestans. The examined starch cultivars show high resistance to $P$. infestans, but their cultivation in organic farming seems to be restricted due to other features' for example very long vegetation period. On the contrary, the group of tested potato breeding lines seems to be very useful for organic farming since they are high yielding and display relatively short vegetation period and high resistance to $P$. infestans. Moreover, these clones produce tubers with an attractive tuber appearance that is indispensable for table potatoes.
\end{abstract}

Key words: potato; Phytophthora infestans; resistance of potato cultivars; organic farming

\section{Streszczenie}

Przedstawione badania dotyczą oceny 10 odmian (5 jadalnych i 5 skrobiowych) oraz 9 klonów hodowlanych ziemniaka pod względem poziomu odporności na Phytophthora infestans oraz wybranych cech użytkowych (długość wegetacji, wysokość plonu, wielkość bulwy, regularność zarysu, głębokość oczek). Badania te miały na celu określenie ewentualnej przydatności badanych form do upraw ekologicznych. Wyniki badań wskazują, że żadna z badanych odmian jadalnych nie powinna być rekomendowana do upraw ekologicznych ze względu na bardzo niski poziom odporności na P. infestans. Badane odmiany skrobiowe posiadają wysoki poziom odporności na $P$. infestans, bardzo pożądany w uprawach ekologicznych. Jednakże ich wykorzystanie w tym celu może być ograniczone przez niedobory innych cech użytkowych (np. bardzo długą wegetację). Natomiast grupa badanych klonów hodowlanych charakteryzowała się bardzo wysokim poziomem odporności na $P$. infestans, skróconym okresem wegetacji, wysokim plonem oraz atrakcyjnym wyglądem bulw.

Słowa kluczowe: ziemniak; Phytophthora infestans; odporność odmian ziemniaka; rolnictwo ekologiczne

Instytut Hodowli i Aklimatyzacji Roślin - Państwowy Instytut Badawczy

Oddział w Młochowie

Platanowa 19, 05-831 Młochów

*corresponding author: j.plich@ihar.edu.pl 


\section{Wstęp / Introduction}

Zaraza ziemniaka wywoływana przez Phytophthora infestans (Mont.) de Bary należy do chorób o największym znaczeniu gospodarczym. Corocznie powoduje ona globalnie duże spadki plonów ziemniaka oraz pochłania ogromne nakłady finansowe na ochronę chemiczną upraw (Haverkort i wsp. 2008). Skuteczną metodą ograniczania negatywnych skutków występowania zarazy ziemniaka jest uprawa odmian o wysokim poziomie odporności. Cecha ta jest szczególnie ważna dla odmian rekomendowanych do uprawy w warunkach rolnictwa ekologicznego, gdzie możliwości ochrony ziemniaka są bardzo ograniczone. W uprawach konwencjonalnych wysoki poziom odporności odmian jest ważnym elementem integrowanej ochrony, który umożliwia obniżenie dawek fungicydu lub wydłużenie przerw między kolejnymi zabiegami ochrony (Kapsa 2002; Bain i wsp. 2008; Naerstad i wsp. 2010). Niestety, zarówno w Polsce, jak i na świecie, większość powszechnie uprawianych odmian ziemniaka jest podatna na zaraze ziemniaka (Kapsa 2005; Forbes 2012). W 2013 roku, w polskim rejestrze odmian ziemniaka, na 126 zarejestrowanych odmian, zaledwie jedna odmiana jadalna i dziesięć odmian skrobiowych wyróżniało się podwyższoną odpornością (ocena $\geq 6$ w skali 1-9) (Nowacki i wsp. 2013). Wyraźny niedobór odmian odpornych widoczny jest zwłaszcza $w$ grupie odmian jadalnych, rejestrowanych przede wszystkim na podstawie plonu dobrej jakości bulw. Brak wysokoodpornych odmian jadalnych ziemniaka powoduje znaczne ograniczenie możliwości doboru odmian do upraw ekologicznych (Zarzyńska 2009). Dużym problemem jest również brak wysokoodpornych odmian o krótkiej wegetacji (Zimnoch-Guzowska i Tatarowska 2004). Fakt ten wynika z silnej korelacji między wysokim poziomem odporności a długą wegetacją roślin ziemniaka (Visker 2005; Plich 2007). Większość odmian o podwyższonej odporności należy do grupy późnych odmian skrobiowych. Wyhodowanie wysokoodpornych odmian ziemniaka o skróconym okresie wegetacji oraz charakteryzujących się jednocześnie zestawem cech jakościowych pożądanych przez konsumenta, jest celem prac hodowlanych na całym świecie. W Instytucie Hodowli i Aklimatyzacji Roślin - Państwowym Instytucie Badawczym (IHAR - PIB), Oddział Młochów od szeregu lat prowadzone są badania nad odpornością roślin ziemniaka na $P$. infestans oraz prace hodowlane ukierunkowane na uzyskanie klonów odpornych na tego patogena.

Celem badań była ocena i porównanie poziomu odporności wybranych odmian jadalnych i skrobiowych oraz rodów hodowlanych ziemniaka na porażenie przez $P$. infestans. Badane odmiany/klony ziemniaka oceniono także pod względem szeregu innych cech, istotnych dla ziemniaka jadalnego przydatnego do upraw ekologicznych, takich jak: długość okresu wegetacji, wysokość plonu oraz morfologia bulw.

\section{Materiały i metody / Materials and methods}

Materiał badawczy stanowiło 10 odmian oraz 9 klonów hodowlanych ziemniaka. Badane odmiany należą do różnych typów użytkowych i różnych grup wczesności. Wśród badanych odmian ziemniaka pięć (bardzo wczesna - Felka Bona, wczesne: Vineta, Bila, Korona oraz średnio wczesna - Kolia) należy do grupy odmian jadalnych. Pozostałe pięć (Bzura, Hinga, Inwestor, Jasia oraz Neptun) to późne odmiany skrobiowe. Wszystkie badane klony hodowlane należą do półrodzeństwa, którego formą mateczną był klon TG97-403. Klon ten jest donorem odporności na $P$. infestans, opartej o działanie genu głównego odporności Rpi-phul. Formy ojcowskie tych klonów to odmiany jadalne: Felka Bona (dla klonów F403-75, F403-82 i F403-90), Korona (dla klonów K40338, K403-78 i K403-84) oraz zaawansowany ród hodowlany PS1763 (dla klonów P403-5, P403-33 i P403-87). Wszystkie badane odmiany i klony hodowlane ziemniaka były oceniane pod względem odporności na $P$. infestans, długości okresu wegetacji oraz wysokości i jakości uzyskanego plonu bulw w latach 2008-2009.

Poziom odporności naci oceniano w doświadczeniu polowym, w warunkach silnej naturalnej presji infekcyjnej. Doświadczenia te zlokalizowane były na polu doświadczalnym Podkarpackiego Ośrodka Doradztwa Rolniczego w Boguchwale. Na poletkach tych zastosowano standardowe dla produkcji ziemniaka jadalnego nawożenie oraz ochronę chemiczną, z wyłączeniem zabiegów fungicydami. Poziom odporności każdego obiektu oceniano na poletkach 6-krzakowych w dwóch powtórzeniach. Dwuredlinowe poletka $\mathrm{z}$ obiektami badań przedzielone były redliną odmiany podatnej (infektora). Ocen dokonywano w odstępach siedmiodniowych (w okresie od początku czerwca do połowy września) poprzez określenie procentu powierzchni porażonej naci każdego obiektu doświadczalnego (Sieczka 2001). Na podstawie cotygodniowych ocen wyznaczono krzywą postępu choroby i wyliczono współczynnik rAUDPC (relative Area Under Disease Progress Curve) według wzoru Frya (1978), który przyjmuje wartości w zakresie od 0 do 1 . Niskie wartości rAUDPC oznaczają niewielki stopień porażenia roślin, czyli wysoki poziom odporności odmiany/klonu.

Długość okresu wegetacji badanych odmian/klonów ziemniaka oceniano na poletkach doświadczalnych IHAR - PIB w Młochowie, według Metodyki prowadzenia badań i obserwacji w doświadczeniach wstępnych (Ratuszniak i Komorowska-Jędrys 1995). W badaniach zastosowano standardowe nawożenie i pełną ochronę chemiczną roślin. Po zakończeniu doświadczenia bulwy zebrano, a następnie określono wysokość plonu oraz najważniejsze cechy morfologiczne bulw, decydujące o przydatności odmiany/klonu do kierunku jadalnego. Morfologia bulw oceniana była według metodyki stosowanej do opisu rodów hodowlanych w IHAR - PIB Oddział Młochów (Domański 2001). Wielkość bulw, regularność zarysu oraz głębokość oczek wyrażane były w skali 1-9, gdzie 9 - oznaczało ocenę najlepszą.

Do analizy statystycznej uzyskanych wyników zastosowano jednoczynnikową analizę wariancji (ANOVA) oraz wyznaczono grupy jednorodne za pomoca testu HSD Tukeya. Analizy statystyczne wykonano w programie STATISTICA v. 10. 


\section{Wyniki i dyskusja / Results and discussion}

Kluczowym elementem decydującym o powodzeniu i opłacalności ekologicznej produkcji ziemniaka jest właściwy dobór odmiany. Optymalny zestaw cech, jaki powinny posiadać odmiany rekomendowane do upraw ekologicznych, to: i) wysoki poziom odporności na $P$. infestans (oraz inne agrofagi), ii) krótki okres wegetacji, iii) możliwie wysoki plon bulw o ładnym wyglądzie i pożądanych cechach ziemniaka jadalnego (Zarzyńska i Goliszewski 2008, 2013). Wyhodowanie odmian ziemniaka łączących wszystkie te cechy jest bardzo trudne, dlatego w doborze odmian właściwie brak jest odmian ziemniaka przeznaczonych do upraw ekologicznych. Wyniki prezentowanych doświadczeń wskazują, że możliwe jest uzyskanie form ziemniaka, łączących wysoki poziom odporności na $P$. infestans z pożądanym zestawem cech użytkowych.

$\mathrm{W}$ przeprowadzonym doświadczeniu badane odmiany jadalne, skrobiowe i klony hodowlane ziemniaka wykazały istotne zróżnicowanie poziomu odporności na $P$. infestans $(\mathrm{P}<0,000)$. Odmiany jadalne ziemniaka uległy silnemu porażeniu przez $P$. infestans, natomiast stopień porażenia odmiany skrobiowych był niski (tab. 1, rys. 1). Wszystkie badane klony hodowlane ziemniaka uległy bardzo słabemu porażeniu przez $P$. infestans. Średnie wartości rAUDPC tych klonów (zakres 0,001-0,091) były zbliżone lub nawet niższe $\mathrm{w}$ porównaniu do średnich wartości rAUDPC odmian skrobiowych (tab. 1, rys. 1). Badana grupa odmian/klonów ziemniaka była zróżnicowana również pod względem długości okresu wegetacji $(\mathrm{P}<0,000)$. Najkrótszym okresem wegetacji charakteryzowała się odmiana Vineta (średnio 111,5 dni wegetacji), Bila (średnio 119,5 dni) oraz klon F403-90 (średnio 115 dni). Dla pozostałych klonów hodowlanych oraz odmian jadalnych oceny długości wegetacji były bardzo zbliżone (zakres średnich 120,5-129 dni). Długość okresu wegetacji odmian skrobiowych była istotnie dłuższa od wegetacji odmian jadalnych i klonów hodowlanych (tab. 1, rys. 2).

Przeprowadzona jednoczynnikowa ANOVA wykazała również zróżnicowanie badanych odmian/klonów ziemniaka pod względem wysokości plonu $(\mathrm{P}<0,000)$, regularności zarysu $(\mathrm{P}=0,002)$, wielkości bulw $(\mathrm{P}=0,01)$ oraz głębokości oczek $(P=0,01)$. Do form najwyżej plonujących można zaliczyć całą grupę klonów hodowlanych oraz dwie odmiany skrobiowe (Inwestor, Jasia) i jedną jadalną (Felka Bona) (tab. 2). Natomiast najniżej plonowała jadalna odmiana Kolia (średnio $0,655 \mathrm{~kg} / \mathrm{krzak}$ ). Odmiana ta miała również najdrobniejsze bulwy (średnia wielkość 3,5 w skali 1-9). Regularność zarysu oraz głębokość oczek badanych odmian/klonów były na zbliżonym poziomie (tab. 2). Jedynie odmiana Hinga (regularność zarysu $=5,0$; głębokość oczek $=5,5$ ) oraz klon K403-38 (głębokość oczek $=5,5$ ) wykazały nieco niższy poziom tych cech (tab. 2).

Wyniki przeprowadzonej polowej oceny odporności na $P$. infestans potwierdzają, że wszystkie badane odmiany jadalne charakteryzują się bardzo niskim poziomem odporności na tego patogena. Odmiany ziemniaka o tak niskim poziomie odporności wymagają pełnej ochrony chemicznej przeciwko $P$. infestans nawet przy niewielkiej presji ze strony patogena. Ponadto, obserwowana w doświadczeniu długość okresu wegetacji badanych odmian jadalnych była nieco dhuższa, niż wynikałoby to $\mathrm{z}$ ich ocen katalogowych. Średnia długość okresu wegetacji odmiany Vineta, Bila, Felka Bona i Korona mieściła się w zakresie typowym dla odmian średnio wczesnych, natomiast odmiany Kolia w zakresie odmian średnio późnych. Wysokość plonu bulw odmiany Kolia i Vineta była na bardzo niskim
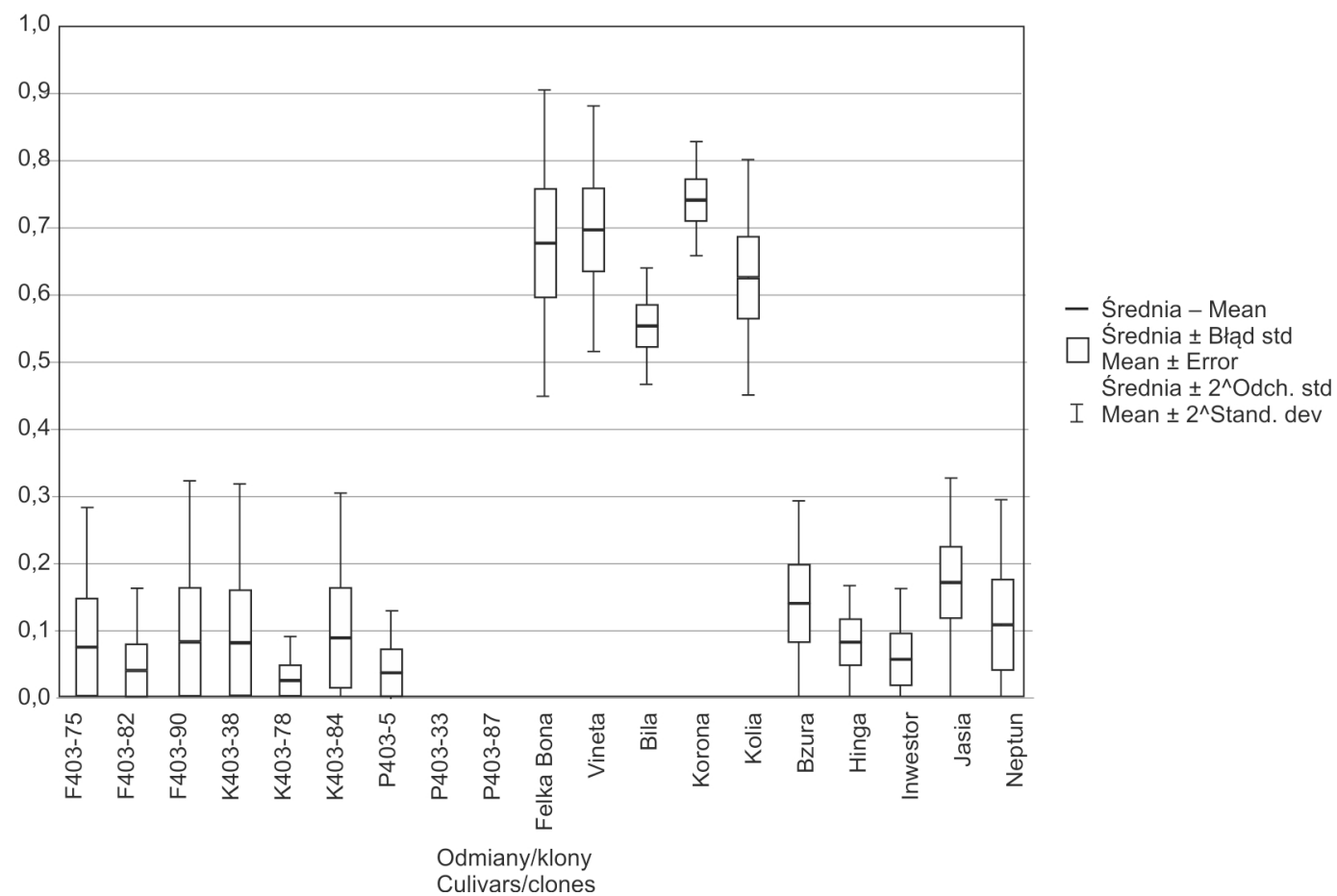

Rys. 1. Wyniki polowej oceny odporności badanych odmian/klonów ziemniaka na Phytophthora infestans

Fig. 1. Results of field assessments of resistance against Phytophthora infestans of potato cultivars/clones 


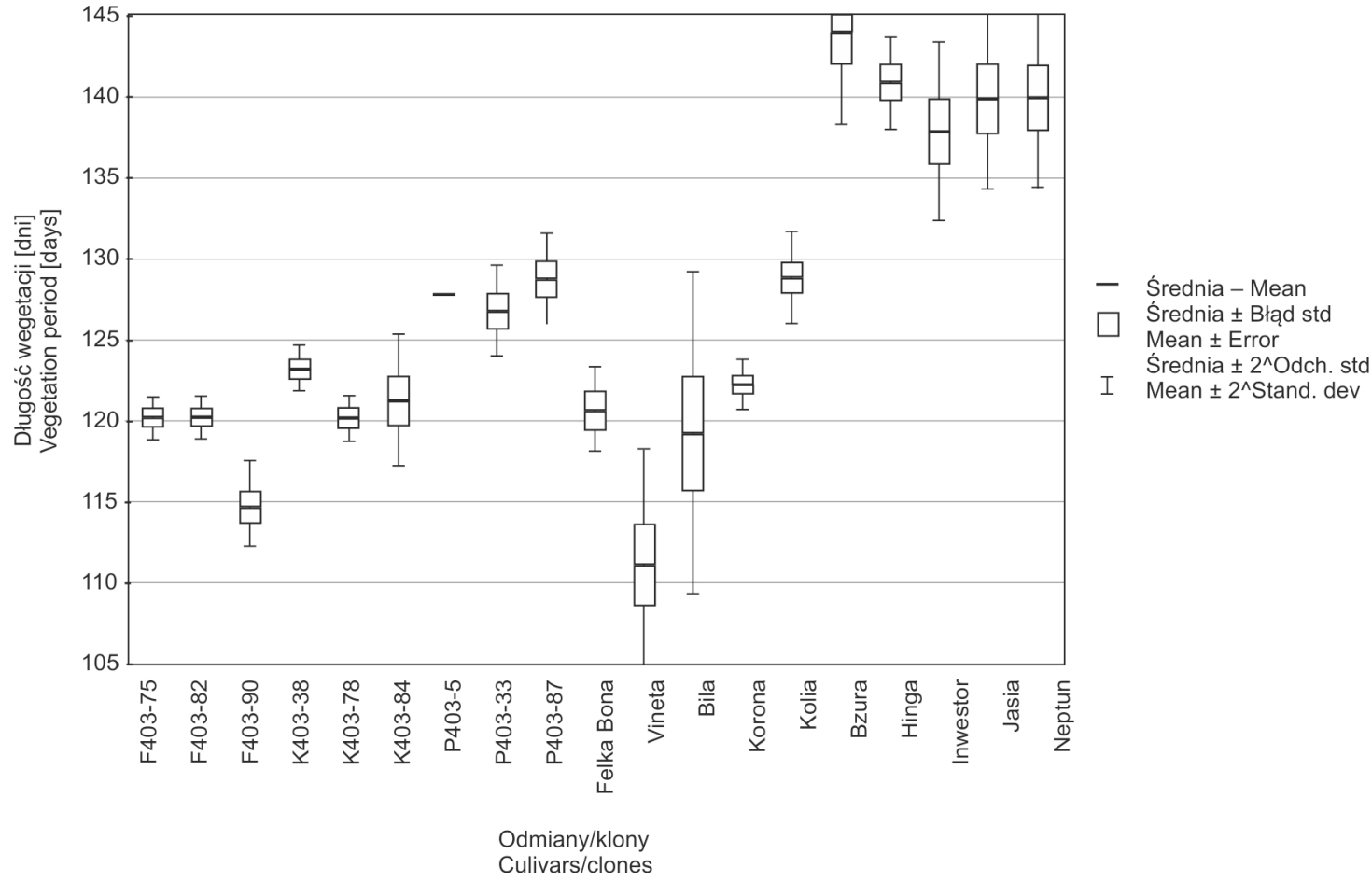

Rys. 2. Wyniki oceny długości okresu wegetacji badanych odmian/klonów ziemniaka

Fig. 2. Results of assessments of length of vegetation period of potato cultivars/clones

Tabela 1. Wyniki oceny badanych odmian/klonów ziemniaka pod względem poziomu odporność na Phytophthora infestans i długości okresu wegetacji

Table 1. Results of evaluation of potato cultivars/clones regarding their resistance to Phytophthora infestans

\begin{tabular}{|c|c|c|c|c|c|}
\hline \multirow{2}{*}{$\begin{array}{l}\text { Odmiana/klon } \\
\text { Cultivar/clone }\end{array}$} & \multirow{2}{*}{$\begin{array}{l}\text { Typ } \\
\text { Type }\end{array}$} & \multicolumn{2}{|c|}{ rAUDPC } & \multicolumn{2}{|c|}{$\begin{array}{l}\text { Długość wegetacji } \\
\text { Length of vegetation period }\end{array}$} \\
\hline & & $\begin{array}{l}\text { średnia } \\
\text { mean value }\end{array}$ & $\begin{array}{l}\text { grupy jednorodne } \\
\text { homogenous group }\end{array}$ & $\begin{array}{c}\text { średnia }[\text { dni] } \\
\text { mean value [days] }\end{array}$ & $\begin{array}{l}\text { grupy jednorodne } \\
\text { homogenous group }\end{array}$ \\
\hline F403-75 & klon - clone & 0,076 & $\mathrm{~A}^{1}$ & 120,5 & $\mathrm{BCD}^{1}$ \\
\hline F403-82 & klon - clone & 0,043 & A & 120,5 & $\mathrm{BCD}$ \\
\hline F403-90 & klon-clone & 0,084 & $\mathrm{~A}$ & 115 & $\mathrm{AB}$ \\
\hline K403-38 & klon - clone & 0,084 & $\mathrm{~A}$ & 123,5 & $\mathrm{BCD}$ \\
\hline K403-78 & klon-clone & 0,026 & A & 120,5 & $\mathrm{BCD}$ \\
\hline K403-84 & klon-clone & 0,091 & $\mathrm{~A}$ & 121,5 & $\mathrm{BCD}$ \\
\hline P403-5 & klon-clone & 0,034 & A & 128 & $\mathrm{CD}$ \\
\hline P403-33 & klon - clone & 0,001 & $\mathrm{~A}$ & 127 & $\mathrm{CD}$ \\
\hline P403-87 & klon-clone & 0,001 & A & 129 & $\mathrm{D}$ \\
\hline Felka Bona & jadalna - table & 0,670 & $\mathrm{~B}$ & 121 & $\mathrm{BCD}$ \\
\hline Vineta & jadalna - table & 0,695 & $\mathrm{~B}$ & 111,5 & A \\
\hline Bila & jadalna - table & 0,550 & $\mathrm{~B}$ & 119,5 & $\mathrm{ABC}$ \\
\hline Korona & jadalna - table & 0,736 & $\mathrm{~B}$ & 122,5 & $\mathrm{BCD}$ \\
\hline Kolia & jadalna - table & 0,622 & $\mathrm{~B}$ & 129 & $\mathrm{D}$ \\
\hline Bzura & skrobiowa - starch & 0,143 & A & 144 & $\mathrm{E}$ \\
\hline Hinga & skrobiowa - starch & 0,085 & A & 141 & $\mathrm{E}$ \\
\hline Inwestor & skrobiowa - starch & 0,059 & A & 138 & $\mathrm{E}$ \\
\hline Jasia & skrobiowa - starch & 0,169 & A & 140 & $\mathrm{E}$ \\
\hline Neptun & skrobiowa - starch & 0,109 & A & 140 & $\mathrm{E}$ \\
\hline
\end{tabular}

rAUDPC - relatywna powierzchnia pod krzywą postępu choroby - relative Area Under Disease Progress Curve

${ }^{1}$ te same litery przy wartościach średnich oznaczają brak statystycznie istotnych różnic $w$ teście Tukeya - mean values followed by the same letter are not significantly different according to Tukey's test 
Tabela 2. Wyniki oceny badanych odmian/klonów ziemniaka pod względem wysokości plonu oraz cech morfologicznych bulw Table 2. Results of evaluation of potato cultivars/clones regarding yield and morphological characters of tubers

\begin{tabular}{|c|c|c|c|c|c|c|c|c|c|}
\hline \multirow{2}{*}{$\begin{array}{l}\text { Odmiana/klon } \\
\text { Cultivar/clone }\end{array}$} & \multirow{2}{*}{$\begin{array}{l}\text { Typ } \\
\text { Type }\end{array}$} & \multicolumn{2}{|c|}{$\begin{array}{c}\text { Plon } \\
\text { [kg/krzak] } \\
\text { Yield } \\
{[\mathrm{kg} / \text { bush }]}\end{array}$} & \multicolumn{2}{|c|}{$\begin{array}{c}\text { Wielkość bulw } \\
\text { [skala 1-9] } \\
\text { Tuber size } \\
\text { [scale 1-9] }\end{array}$} & \multicolumn{2}{|c|}{$\begin{array}{c}\text { Regularność zarysu } \\
\text { [skala 1-9] } \\
\text { Tuber shape } \\
\text { regularity } \\
\text { [scale 1-9] }\end{array}$} & \multicolumn{2}{|c|}{$\begin{array}{c}\text { Głębokość oczek } \\
\text { [skala 1-9] } \\
\text { Depth of eyes } \\
\text { [scale 1-9] }\end{array}$} \\
\hline & & $\begin{array}{l}\text { średnia } \\
\text { mean } \\
\text { value }\end{array}$ & $\begin{array}{l}\text { grupy } \\
\text { jedno- } \\
\text { rodne } \\
\text { homo- } \\
\text { genous } \\
\text { group }\end{array}$ & $\begin{array}{l}\text { średnia } \\
\text { mean } \\
\text { value }\end{array}$ & $\begin{array}{l}\text { grupy } \\
\text { jedno- } \\
\text { rodne } \\
\text { homo- } \\
\text { genous } \\
\text { group }\end{array}$ & $\begin{array}{l}\text { średnia } \\
\text { mean } \\
\text { value }\end{array}$ & $\begin{array}{l}\text { grupy } \\
\text { jedno- } \\
\text { rodne } \\
\text { homo- } \\
\text { genous } \\
\text { group }\end{array}$ & $\begin{array}{c}\text { średnia } \\
\text { mean } \\
\text { value }\end{array}$ & $\begin{array}{l}\text { grupy } \\
\text { jedno- } \\
\text { rodne } \\
\text { homo- } \\
\text { genous } \\
\text { group }\end{array}$ \\
\hline F403-75 & klon-clone & 1,515 & $\mathrm{ABCD}^{1}$ & 5,8 & $\mathrm{AB}^{1}$ & 6,9 & $\mathrm{~A}^{1}$ & 6,8 & $\mathrm{AB}^{1}$ \\
\hline F403-82 & klon - clone & 1,330 & $\mathrm{ABCDE}$ & 5,8 & $\mathrm{AB}$ & 6,7 & A & 7,3 & $\mathrm{~A}$ \\
\hline F403-90 & klon - clone & 1,312 & $\mathrm{ABCDE}$ & 5,8 & $\mathrm{AB}$ & 6,9 & $\mathrm{~A}$ & 7,0 & $\mathrm{AB}$ \\
\hline K403-38 & klon - clone & 1,500 & $\mathrm{ABCD}$ & 5,8 & $\mathrm{AB}$ & 5,5 & $\mathrm{AB}$ & 5,5 & $\mathrm{~B}$ \\
\hline K403-78 & klon - clone & 1,612 & $\mathrm{ABC}$ & 6,0 & $\mathrm{AB}$ & 6,8 & $\mathrm{~A}$ & 6,8 & $\mathrm{AB}$ \\
\hline K403-84 & klon-clone & 1,663 & $\mathrm{AB}$ & 6,5 & $\mathrm{~A}$ & 6,5 & $\mathrm{AB}$ & 6,9 & $\mathrm{AB}$ \\
\hline P403-5 & klon-clone & 1,969 & $\mathrm{~A}$ & 6,5 & $\mathrm{~A}$ & 6,2 & $\mathrm{AB}$ & 6,3 & $\mathrm{AB}$ \\
\hline P403-33 & klon - clone & 1,665 & $\mathrm{AB}$ & 5,5 & $\mathrm{AB}$ & 6,5 & $\mathrm{AB}$ & 6,3 & $\mathrm{AB}$ \\
\hline P403-87 & klon-clone & 1,933 & A & 6,3 & $\mathrm{~A}$ & 6,3 & $\mathrm{AB}$ & 6,8 & $\mathrm{AB}$ \\
\hline Felka Bona & jadalna - table & 1,252 & $\mathrm{ABCDE}$ & 5,0 & $\mathrm{AB}$ & 6,9 & $\mathrm{~A}$ & 6,6 & $\mathrm{AB}$ \\
\hline Vineta & jadalna - table & 0,790 & $\mathrm{DE}$ & 4,4 & $\mathrm{AB}$ & 6,6 & $\mathrm{~A}$ & 6,9 & $\mathrm{AB}$ \\
\hline Bila & jadalna - table & 0,837 & $\mathrm{BCDE}$ & 4,8 & $\mathrm{AB}$ & 6,8 & A & 6,8 & $\mathrm{AB}$ \\
\hline Korona & jadalna - table & 1,090 & $\mathrm{BCDE}$ & 4,7 & $\mathrm{AB}$ & 6,2 & $\mathrm{AB}$ & 5,9 & $\mathrm{AB}$ \\
\hline Kolia & jadalna - table & 0,655 & $\mathrm{E}$ & 3,5 & $\mathrm{~B}$ & 6,8 & $\mathrm{~A}$ & 6,3 & $\mathrm{AB}$ \\
\hline Bzura & skrobiowa - starch & 0,955 & $\mathrm{BCDE}$ & 4,9 & $\mathrm{AB}$ & 6,5 & $\mathrm{AB}$ & 6,4 & $\mathrm{AB}$ \\
\hline Hinga & skrobiowa - starch & 0,890 & $\mathrm{BCDE}$ & 4,7 & $\mathrm{AB}$ & 5,0 & $\mathrm{~B}$ & 5,5 & $\mathrm{~B}$ \\
\hline Inwestor & skrobiowa - starch & 1,470 & $\mathrm{ABCD}$ & 5,2 & $\mathrm{AB}$ & 5,7 & $\mathrm{AB}$ & 5,6 & $\mathrm{AB}$ \\
\hline Jasia & skrobiowa - starch & 1,372 & $\mathrm{ABCDE}$ & 5,8 & $\mathrm{AB}$ & 6,0 & $\mathrm{AB}$ & 6,0 & $\mathrm{AB}$ \\
\hline Neptun & skrobiowa - starch & 1,035 & $\mathrm{BCDE}$ & 6,0 & $\mathrm{AB}$ & 6,0 & $\mathrm{AB}$ & 6,0 & $\mathrm{AB}$ \\
\hline
\end{tabular}

${ }^{1}$ te same litery przy wartościach średnich oznaczają brak statystycznie istotnych różnic w teście Tukeya - mean values followed by the same letter are not significantly different according to Tukey's test

poziomie, a odmian Bila i Korona na średnim poziomie. Wśród odmian jadalnych jedynie Felka Bona osiągnęła wysoki plon bulw, który nie różnił się od plonu badanych odmian skrobiowych czy klonów hodowlanych. Ocena cech morfologicznych bulw badanych odmian jadalnych była na dobrym poziomie, a jedynie odmiana Kolia wyróżniała się bardzo drobnymi bulwami (tab. 2).

Wyniki polowej oceny odmian skrobiowych potwierdzają wysoki poziom odporności na $P$. infestans, który może stanowić skuteczny element walki $\mathrm{z}$ zarazą ziemniaka w warunkach rolnictwa ekologicznego. Przy niskiej presji infekcyjnej ze strony $P$. infestans odmiany ziemniaka, o takim poziomie odporności na zarazę ziemniaka, mogą pozostać przez cały sezon bez ochrony chemicznej (Kapsa 2005). Badane odmiany skrobiowe charakteryzują się jednak bardzo długim okresem wegetacji ( 140 dni). Cecha ta ogranicza możliwość ich wykorzystania do upraw ekologicznych, gdzie preferowane są odmiany wcześniejsze (Zarzyńska i Goliszewski 2013). Plon bulw odmian Inwestor i Jasia był na wysokim poziomie, a pozostałych odmian skrobiowych na średnim poziomie. Cechy morfologiczne bulw badanych odmian skrobiowych również były na dobrym poziomie. Jedynie odmiana Hinga wyróżniała się najsłabszą wśród testowanych odmian/klonów regularnością zarysu i głębokością oczek (tab. 2).

Badane klony hodowlane ziemniaka wykazały bardzo wysoki poziom odporności na $P$. infestans. Klony te uległy bardzo słabemu porażeniu przez $P$. infestans, a średnie wartości rAUDPC były porównywalne lub nawet niższe od rAUDPC późnych odmian skrobiowych. Jednocześnie, klony te charakteryzowały się skróconym okresem wegetacji, podobnie jak badane odmiany jadalne. Połączenie wysokiej odporności na $P$. infestans ze skróconym okresem wegetacji jest bardzo cenne, ze względu na powszechne występowanie silnej negatywnej korelacji tych dwóch cech (Świeżyński 1990; Visker 2005; Plich 2007). W badanych klonach hodowlanych połączenie to osiągnięto dzięki wykorzystaniu nowego źródła odporności na $P$. infestans, opartego o działanie genu Rpi-phu1 (Śliwka i wsp. 2006; Plich i wsp. 2013). Ponadto, badane klony hodowlane wyróżniały się wysokim plonem bulw o dobrej morfologii. Formy te posiadają również dobre właściwości kulinarne. 
Wyniki prezentowanych badań potwierdzają ograniczoną przydatność badanych odmian ziemniaka do upraw ekologicznych. Żadna z odmian jadalnych nie powinna być rekomendowana do upraw ekologicznych, ze względu na bardzo niski poziom odporności na $P$. infestans. Odmiany skrobiowe charakteryzują się wysokim poziomem odporności na zarazę ziemniaka, a wysokość i jakość uzyskanego plonu bulw jest na akceptowalnym poziomie. Mimo to, ich przydatność do upraw ekologicznych może być ograniczona, ze względu na bardzo długi okres wegetacji. Większość tych odmian nie spełnia również wymagań konsumentów w zakresie właściwości kulinarnych. Wyniki oceny badanych rodów hodowlanych ziemniaka wskazują na przydatność tych klonów do uprawy w warunkach rolnictwa ekologicznego. Klony te posiadają bardzo wysoki poziom odporności na zarazę ziemniaka, połączony ze skróconym okresem wegetacji oraz wysokim poziomem cech ziemniaka jadalnego.

\section{Wnioski / Conclusions}

1. Badane odmiany jadalne (Felka Bona, Vineta, Bila, Korona i Kolia) nie powinny być rekomendowane do upraw ekologicznych, ze względu na bardzo niski poziom odporności na $P$. infestans.

2. Badane odmiany skrobiowe (Bzura, Hinga, Inwestor, Jasia, Neptun) charakteryzują się wysokim poziomem odporności na $P$. infestans, który może stanowić skuteczny element walki z zarazą ziemniaka w warunkach rolnictwa ekologicznego. Jednak możliwość ich wykorzystania w uprawach ekologicznych może być ograniczona, ze względu na bardzo długi okres wegetacji oraz niski poziom walorów ziemniaka jadalnego tych odmian.

3. Badana grupa klonów hodowlanych posiada zestaw cech bardzo pożądanych dla odmian przeznaczonych do upraw ekologicznych. Klony te łączą w sobie wysoki poziom odporności na $P$. infestans ze skróconą wegetacją oraz wysokim plonem bulw dobrej jakości.

\section{Literatura / References}

Bain R.A., Bradshaw N.J., Ritchie F. 2008. Matching fungicide inputs to cultivar resistance to the control of Phytophthora infestans on potato. p. 283-289. In: Special Reports No. 13. Proceeding 11th EuroBlight Workshop (H.T.A.M. Schepers, ed). Norway, Hamar, 28-31 October 2008. Praktijkonderzoek Plant \& Omgeving (PPO) 384, 320 pp.

Domański L. 2001. Ocena morfologicznych cech bulw ziemniaka. Monografie i Rozprawy Naukowe Instytutu Hodowli i Aklimatyzacji Roślin 10: 94-98.

Forbes G.A. 2012. Using host resistance to manage potato late blight with particular reference to developing countries. Potato Research 55: 205-216.

Fry W.E. 1978. Quantification of general resistance of potato cultivars and fungicide effects for integrated control of potato late blight. Phytopathology 68: 1650-1655.

Haverkort A.J., Boonekamp P.M., Hutten R., Jacobsen E., Lotz L.A.P., Kessel G.J.T., Visser R.G.F., van der Vossen E.A.G. 2008. Societal costs of Late Blight in Potato and prospects of durable resistance through cisgenic modification. Potato Research 51: $47-57$.

Kapsa J. 2002. Potato resistance to late blight - an important element of the protection strategy. p. 125-130. In: Special Report No. 8. Proceeding 6th EuroBlight Workshop (C.E. Westerdijk, H.T.A.M. Schepers, eds.). Scotland, Edinburgh, $26-30$ September 2001. Praktijkonderzoek Plant \& Omgeving (PPO) 304, 280 pp.

Kapsa J. 2005. Wykorzystanie odporności odmian w ochronie ziemniaka przed zarazą. Ziemniak Polski 5: 20-22.

Naerstad R., Le V.H., Hermansen A. 2010. Reduced fungicide input in late blight control (REDUCE 2007-2011) Preliminary results. p. 193-198. In: Special Report No. 14. Proceeding 12th EuroBlight Workshop (H.T.A.M Schepers, ed.). France, Arras, 3-6 May, 2010. Praktijkonderzoek Plant \& Omgeving (PPO) 396, 316 pp.

Nowacki W., Boguszewska D., Czerko Z., Goliszewski W., Grudzińska M., Jankowska J., Lutomirska B., Pietraszko M., Trawczyński C., Wierzbicka A., Zarzyńska K., Zgórska K., Michalak K. 2013. Charakterystyka krajowego Rejestru odmian ziemniaka. Wydanie XVI. IHAR - PIB, Jadwisin, 42 ss.

Plich J. 2007. Odporność roślin ziemniaka na Phytophthora infestans i jej związek z wczesnością odmian - przegląd literatury. Biuletyn Instytutu Hodowli i Aklimatyzacji Roślin 246: 61-71.

Plich J., Tatarowska B., Flis B. 2013. Związek odporności bulw ziemniaka na porażenie Phytophthora infestans z odpornością naci. [Potato tuber resistance to Phytophthora infestans and its relationship with foliage resistance]. Progress in Plant Protection/Postępy w Ochronie Roślin 53 (3): 552-555.

Ratuszniak E., Komorowska-Jędrys J. 1995. Metodyka prowadzenia badań i obserwacji w doświadczeniach wstępnych z rodami hodowlanymi (odmianami) ziemniaka (instrukcja). Instytut Ziemniaka, Bonin, 33 ss.

Sieczka M.T. 2001. Ocean odporności na zarazę ziemniaka w warunkach naturalnej infekcji. IHAR, Radzików, Monografie i rozprawy naukowe 10: 74-76.

Śliwka J., Jakuczun H., Lebecka R., Marczewski W., Gebhardt C., Zimnoch-Guzowska E. 2006. The novel, major locus Rpi-phu1 for late blight resistance maps to potato chromosome IX and is not correlated with long vegetation period. Theoretical and Applied Genetics 113: 685-695.

Świeżyński K. 1990. Resistance to Phytophthora infestans in potato cultivars and its relation to maturity. Genetica Polonica 31: 99-106.

Visker M.H.P.W. 2005. Association between late blight resistance and foliage maturity type in potato: Physiological and genetical studies. Ph.D. thesis. Wageningen University, the Netherlands, $160 \mathrm{pp}$.

Zarzyńska K. 2009. Problemy ekologicznej uprawy ziemniaków w Polsce i krajach UE. Ziemniak Polski 3: 1-4.

Zarzyńska K., Goliszewski W. 2008. Ocena przydatności kilku odmian ziemniaka do uprawy w systemie ekologicznym i integrowanym na różnych kompleksach glebowych. Journal of Research and Applications in Agricultural Engineering 53 (4): 148-152.

Zarzyńska K., Goliszewski W. 2013. Polskie czy zagraniczne odmiany ziemniaka do uprawy ekologicznej? Ziemniak Polski 2: 19-23.

Zimnoch-Guzowska E., Tatarowska B. 2004. Bottle necks in breeding late blight resistant potato. Plant Breeding and Seed Science 50: 71-79. 